\title{
Importance of Indigenous Knowledge in Biodiversity Conservation: A Case Study of Communities Surrounding Kpashimi Forest Reserve, Niger State, Nigeria
}

\author{
*Jibrin Abdullahi. ${ }^{1}$, Isyaku Usman. ${ }^{1}$, Garba Samaila. ${ }^{1}$ Aminu Zuni. ${ }^{2}$ \\ ${ }^{I}$ Department of Geography, Ahmadu Bello University, Zaria, Nigeria \\ ${ }^{2}$ Ibrahim Badamasi Babangida University, Lapai, Nigeria
}

\begin{abstract}
Forest resource use and traditional conservation practices were studied in nine forest neighbouring communities to Kpashimi Forest Reserve, Niger state. The aim of the study was to examine the importance of indigenous knowledge in biodiversity conservation among the communities surrounding Kpashimi Forest Reserve. Ecological survey and Rapid Rural Appraisal methods were adopted for the study. Matrix ranking and scoring was employed to analyse data on communities' utilization of vegetation species. The average rank score for each perceived important value was calculated. Medicinal value was ranked first with average rank score of 1.21, followed by fuel wood (2.33), food (2.62), cultural value (3.72), timber (3.86), building materials (3.92), grazing (5.24), aesthetic (7.10), fibre (7.34), and employment (8.22). Analysis of respondents' perceived relevance of indigenous knowledge on biodiversity conservation indicated weighted mean score statistics and standard deviation ranging between 3.33-4.16 and $0.078-0.596$, respectively. This implies that their mean values were all above the cut-off point of 2.50 and therefore recognised the importance of indigenous knowledge in biodiversity conservation. The study revealed that existing traditional conservation methods among the natives include preservation of sacred landscapes for threatened species, myths and taboos restricting use through dos and don'ts, harvesting methods, spiritual values associated with forests and individual species. Appreciating these immense values and threats from changing environment, the natives indicated approval for the integration of indigenous knowledge with modern forest management practices. The study therefore contends that for continued sustainability of forest biodiversity, conservation strategies need to recognise local knowledge in both content and practice.
\end{abstract}

Key words: biodiversity, conservation, indigenous knowledge, plant species, traditional.

\subsection{Background to the study}

\section{Introduction}

Biological diversity and sustainable resource use are crucial for ecosystem stability and human survival. However, biodiversity is under assault world over; due to rapid and accelerating anthropogenic activities causing persistent decline in species diversity $[1,2,3,4]$. Consequently, biodiversity conservation has become one of the dilemmas currently facing mankind in both developed and the developing world. $[5,6,7,4]$. The conservation of habitats and landscapes constitutes one of the major targets (target 4 ) of the Convention on Biological Diversity through its global strategy for plant conservation. Meeting this biodiversity conservation target requires every country or state to engage in systematic conservation planning and related conservation action $[8,9]$. The wide acceptance of sustainable development as a concept has shifted forest management policies from traditional to a people-oriented approach in order to harness local knowledge [10]. For long, developing environmental management plans has been dominated by the so-called trained experts who are hired for the task. However, empirical evidences show that this approach has led to failures because these managers refused to integrate indigenous peoples' knowledge in the affected communities [11].

United Nations Conference on Environment and Development -UNCED, [12] posit that Indigenous knowledge may be defined as the holistic traditional scientific knowledge of a people's lands, natural resources and environment developed over many generations as a result of their interrelationship with the natural environment towards cultural, social, economic and physical well-being of the indigenous people. According to Grenier [13], Indigenous knowledge refers to the unique traditional knowledge existing within and developed around the specific conditions of women and men indigenous to a particular geographic area. Unfortunately, this knowledge system does not find much recognition in modern forest management theories and practices, which are increasingly driven by concepts, tools and practices, which are somewhat alien to the traditional communities. Different scholars have defined indigenous knowledge differently but the common thread that runs through all the definitions are that it should be understood from the people's perspective of the physical environment in which they live, the natural resources they are endowed with and the ways in which these resources can be utilized optimally to cope with the challenges of the environment within the contexts of their 
social and cultural milieu [12]. The onslaught of the so-called modern and quick fix solutions have threatened the vast pool of local knowledge with extinction and therefore it has become extremely important to research, document, revive and replicate, wherever possible, such knowledge and practices and further synergizes them with modern scientific knowledge, especially in the context of promoting sustainable forest management [14].

For ecologists, traditional ecological knowledge offers a means to improve research and also to improve resource management and environmental impact assessment $[15,16]$. Various advocates of traditional ecological knowledge promote its significance on improvements to scientific research and management through more and sometimes better information [17,18,19]; identification of new paradigms by which we can understand the natural world and our relation to it $[20,21,22]$ and broad societal change away from the positivist and amoral; towards the holistic and ethical $[20,23,24]$. The aim of the study is to examine the importance of indigenous knowledge in biodiversity conservation among the communities surrounding Kpashimi Forest Reserve. The objectives of the study includes to:

i. identify the preference values attached to plant species utilisation;

ii. assess the respondents' perceived relevance of indigenous knowledge on biodiversity conservation;

iii. describe the indigenous practices contributing to biodiversity conservation in the area;

iv. elicit information on perceived status and challenges to the use of indigenous knowledge in biodiversity conservation.

The findings is hoped to assist the government, policy makers and other stakeholders in designing and implementing appropriate programs towards efficient and effective biodiversity conservation framework; especially in developing countries where livelihoods is dependent on exploitation of plant species.

\subsection{Conceptual Framework}

The conceptual framework for this study is the Sustainable forest management (SFM). Sustainable development is development that is economically viable, environmentally benign and socially beneficial, and which balances present and future needs [25,7]. Sustainable forest management is based on methods that jeopardize neither future harvests of forest products nor future benefits of environmental services. The Centre for International Forestry Research defined Sustainable Forest Management as "maintaining or enhancing the contribution of forests to human well-being, both of present and future generations, without compromising their ecosystem integrity, i.e., their resilience, function and biological diversity" [26]. The implication is that, application of good forest management practices substantially helps maintain the value of forests as sources livelihood products, while simultaneously helping to maintain biodiversity and protecting watershed and other ecosystem services.

\subsection{The study area}

\section{Materials And Methods}

The study area is made up of nine Nupe ethnic communities that surround the Kpashimi Forest Reserve including Nassarawa, Fapo, Gulu, Lafian Kpada, Makeri, Kunko, Lafian zago, Zago, and Mayaki. Kpashimi Forest Reserve is located on latitude $8^{\circ} 38^{\prime}$ to $8^{\circ} 52^{\prime}$ North and $6^{\circ} 34^{\prime}$ to $6^{\circ} 48^{\prime}$ East. It is situated about 50 kilometres south of Lapai town on the left hand side of the tarred road from Lapai to Gulu. The forest reserve covers approximately 213.101 square kilometres (see Fig. 1). The study area lies within the tropical hinterland climatic belt of Nigeria. It is characterised by alternating wet and dry season coded as 'Aw' by Koppen's classification (that is tropical rainy climate with dry season in winter). The mean annual rainfall is about 1,300 $\mathrm{mm}$ with mean annual temperature of about $28^{\circ} \mathrm{C}$ The geology of the study area is made up of cretaceous sedimentary rocks underlain by the Precambrian basement complex rocks. [27]. The topography is gently undulating, sloping generally towards different directions in different locations. Soils in the study area based on the CCTA classification system belong to ferruginous tropical soils .A few occupying depressional areas, and valley bottom positions are hydromorphic, while those around the inselbergs and other residual hills, and at the bed of rivers, are weakly developed. The study area lies within the southern Guinea savanna zone characterised by the woodland vegetation type [28]. 


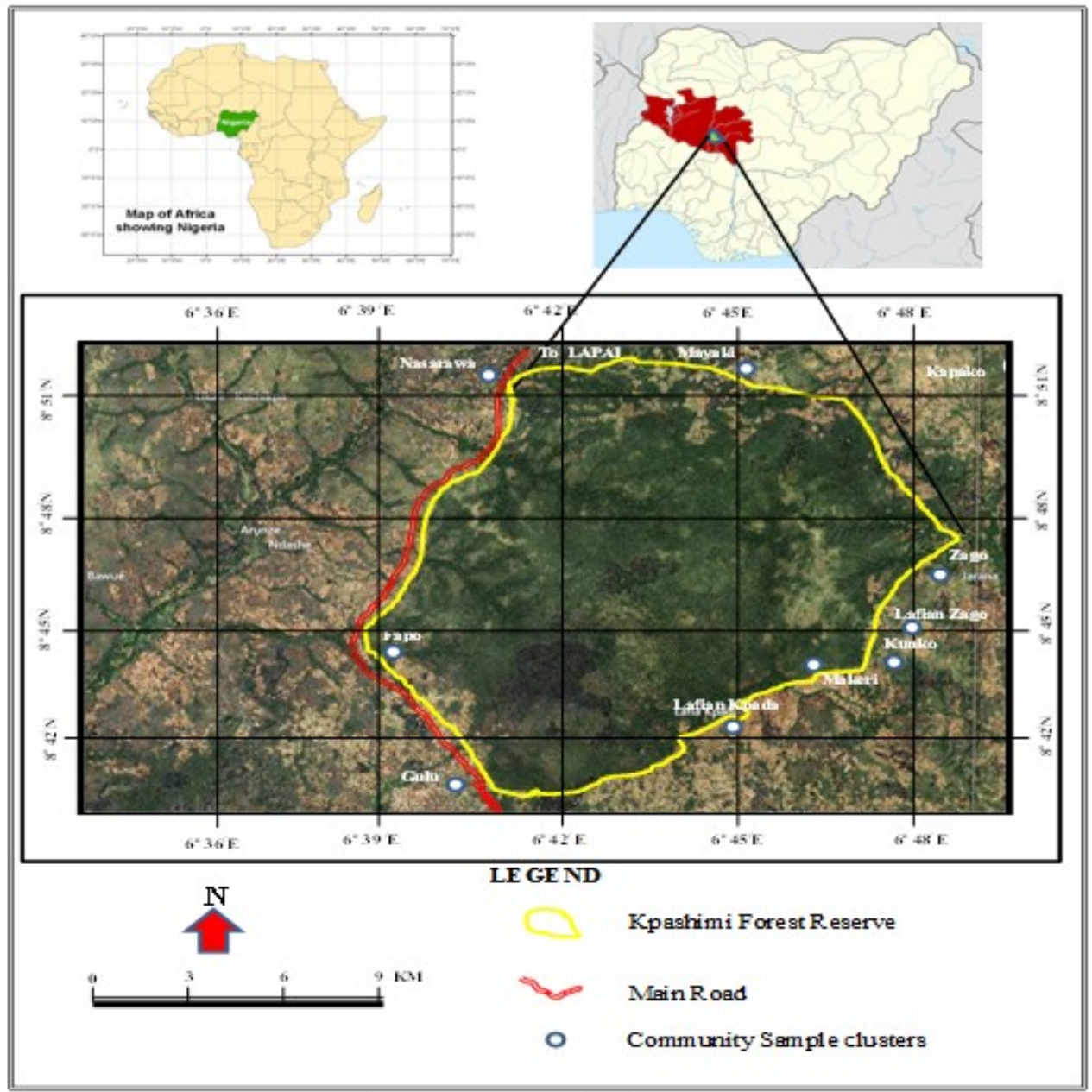

Figure 1: Map of the study area.

\subsection{Methodology}

Ecological survey and Rapid Rural Appraisal methods to examine indigenous strategies was adopted for the study. The research involved descriptive survey design whereby the same information is gathered from an unbiased representative group of interest. Given estimated population of about 30,000, the sample size was determined by using the formula of Yamane, (29).

Where:

$$
n=\frac{N}{1+N(e)^{2}}
$$

$n=$ Sample Size $; \quad N=$ Population size $; 1=$ Constant $\quad e=$ The level of precision

A 95\% confidence level and $\mathrm{P}=0.5$ are assumed for the Equation. This generated a sample size of 395 . Each of the nine communities was considered as a cluster and an equal number of 44 questionnaires were administered randomly in each community. A total of $373(94.4 \%)$ questionnaires were returned. The data was collected from primary and secondary sources. Both quantitative and qualitative data were realized through structured questionnaires, semi structured interviews and Focus Group Discussions in nine selected villages. Focus Group Discussion was used to elicit information on diversities among respondent's interests and perception concerning sustainable forest management. Matrix Ranking and Scoring method [30] was employed to collect information on villagers' preference and perception regarding the importance/value of forest resources. First, the participants were asked to identify, list and rank the importance of their forest resources. Thereafter, matrix ranking was used to determine the villages' preference score for each perceived importance value attached to ten categories of plant species values including timber, food, building materials, medicine, grazing, fibre, fuel wood, cultural, aesthetic, and employment.

The questionnaire was made up of two sections. Section 'A' elicited responses on the relevance of indigenous knowledge on biodiversity conservation; while section 'B' sought information on the constraints to the use of indigenous knowledge in biodiversity conservation. The instrument was a four point rating scale of 
Strongly Agree (SA), Agree (A), Disagree (D) and Strongly Disagree (SD) with a corresponding score value of 4, 3, 2 and 1, respectively. The instrument was face validated and Cronbach alpha reliability method was adopted to determine the internal consistency of the questionnaire items. Cronbach coefficient of 0.83 and 0.77 were obtained for the two sections respectively. The arithmetic mean for the values was computed as $4+3+2+$ $1=10 / 4=2.50$. Therefore, a total mean score of 2.50 and above was used as cut-off point for 'agree' while any mean score below 2.50 indicate disagree. Weighted mean score statistics and standard deviation were used for data analysis.

\subsection{Communities Utilisation of forest resources}

\section{Results}

The key participants were asked to list plant species derived from forests and then ranked in order of importance/preference of use. It was assumed in this study that people ranked species according to their perception on importance-value. Therefore, knowledge of species use would determine the magnitude of value attached to the species.

Notable important tree species utilized in the communities includes: Taura (Ditarium microcarpum) Ciwo (Landolphia owariensis), Gaude (Ceiba pentandra,) Dara (Tamarindus indica,) Kuka (Adansonia digitata) and Mangoro (Mangifera indica). Others are Dinya (Vitex doniana), Vitaleria paradoxa, kwaakwa (Elaeis guineensis) Borassus aethiopum, loko or iroko tree (Chlorophora excelsa) Afzelia Africana, Acacia albida, Tsada (Ximenia Americana) Bombax costatum, Khaya senegalenesis, Gwanon (kurmi Olax sp.) Parkia bigloboza, Hyphaene thebaica, Ceiba pentandra, Yaka (Daniellia oliveri), Ficus sycomorus, Anogeissus leiocarpus, Pterocarpus erinaceus, Kadanya (Butyrospermum parkii) Acacia senegal. Grasses used include janbaujee (Monocymbium ceresiijorme), toofa (Jmperata cylindrica), yamaa (Hyparrhenia rufa), k'yaaraa (Hyparrhenia dissoluta), bauje (Acacia sieberana), and kyasuwa (Pennisetum hordeoides). Favoured parts of these tree species sought for various uses include the pod/fruit, leaf, leaf stem, branches, bark, and the inner part of the branches after removal of the bark, the juice and the trunk. The most common part used is the trunk, followed by branches, leaf and bark.

Table 1: Matrix ranking and average scores attached to plant species values

\begin{tabular}{|l|c|c|c|c|c|c|c|c|c|c|c|c|}
\hline \multirow{2}{*}{\multicolumn{1}{c|}{ VALUES }} & \multicolumn{10}{|c|}{ RANKS } & Average & Rank \\
\cline { 2 - 15 } & $\mathbf{1}$ & $\mathbf{2}$ & $\mathbf{3}$ & $\mathbf{4}$ & $\mathbf{5}$ & $\mathbf{6}$ & $\mathbf{7}$ & $\mathbf{8}$ & $\mathbf{9}$ & $\mathbf{1 0}$ & Rank & Position \\
\hline Timber & 0 & 0 & 127 & 170 & 76 & 0 & 0 & 0 & 0 & 0 & 3.86 & $5^{\text {th }}$ \\
\hline Food & 0 & 210 & 93 & 70 & 0 & 0 & 0 & 0 & 0 & 0 & 2.62 & $3^{\text {rd }}$ \\
\hline Building & 0 & 45 & 70 & 161 & 63 & 34 & 0 & 0 & 0 & 0 & 3.92 & $6^{\text {th }}$ \\
\hline Medicine & 316 & 34 & 23 & 0 & 0 & 0 & 0 & 0 & 0 & 0 & 1.21 & $1^{\text {st }}$ \\
\hline Grazing & 0 & 0 & 0 & 120 & 116 & 64 & 73 & 0 & 0 & 0 & 5.24 & $7^{\text {th }}$ \\
\hline Fibre & 0 & 0 & 0 & 0 & 0 & 23 & 200 & 150 & 0 & 0 & 7.34 & $9^{\text {th }}$ \\
\hline Fuel Wood & 12 & 231 & 123 & 7 & 0 & 0 & 0 & 0 & 0 & 0 & 2.33 & $2^{\text {nd }}$ \\
\hline Cultural Values & 11 & 0 & 150 & 171 & 0 & 41 & 0 & 0 & 0 & 0 & 3.72 & $4^{\text {th }}$ \\
\hline Aesthetics & 0 & 7 & 0 & 0 & 81 & 0 & 137 & 59 & 89 & 0 & 7.10 & $8^{\text {th }}$ \\
\hline Employment & 0 & 0 & 7 & 0 & 0 & 0 & 0 & 257 & 98 & 11 & 8.22 & $10^{\text {th }}$ \\
\hline
\end{tabular}

Note: The ranks are averages of ranks given to each value by each of the 373 indigenous people.

For instance the average rank for Food is $(0 * 1+210 * 2+93 * 3+70 * 4+0 * 5$ etc. $) / 373=2.62$

Table 1 presents data on respondents' ranking of forest plant species importance value. It portrays that Medicinal value was ranked first with average rank score of 1.21, followed by fuel wood (2.33), and food (2.62); while employment was ranked last (8.22). The result shows that the communities depend directly on their natural environment for livelihoods, energy, and cultural heritage. Protection of the forest reserve and significant degradation of non-protected areas makes employment opportunities slim in forestry and hence ranked lowest.

\subsection{Importance of components of indigenous knowledge}

The Importance of indigenous knowledge components were assessed based on the contributions of Botanical knowledge to forest management on knowledge of species characteristics and use properties; Ecological knowledge on growing conditions of plant and animals in the forests; Technical knowledge on silvicultural management practices; Institutional knowledge on norms, rules and regulations for using and managing forest resources within a locality; Behavioural knowledge on community needs and use pattern; Economic knowledge on economic benefits and values of forest produce; and Legal knowledge on national, international, regional and state levels laws and legislation for planting and harvesting. 
Table 2: Mean score rating of perceived importance of components of indigenous knowledge

\begin{tabular}{|l|c|c|c|}
\hline \multicolumn{1}{|c|}{ INDIGENOUS KNOWLEDGE CATEGORY } & $\overline{\mathbf{x}}$ & $\mathbf{S D}$ & DECISION \\
\hline Botanical Knowledge is important & 4.16 & 0.123 & Agree \\
Ecological Knowledge is important & 3.91 & 0.078 & Agree \\
Technical Knowledge is important & 3.89 & 0.682 & Agree \\
Institutional Knowledge is important & 3.53 & 0.087 & Agree \\
Behavioural Knowledge is important & 3.94 & 0.078 & Agree \\
Economic Knowledge is important & 3.88 & 0.596 & Agree \\
Legal Knowledge is important & 3.33 & 0.490 & Agree \\
\hline
\end{tabular}

Note: $\overline{\mathbf{x}}=$ Mean, $\mathbf{S D}=$ Standard deviation

Data on table 1 indicates that the mean scores and standard deviation, range between 3.33- 4.16 and 0.078 0.596 , respectively. This portrays that their mean values were all above the cut-off point of 2.50 which implied that all components of indigenous knowledge were agreed to be important ingredients for achieving sustainable biodiversity conservation.

\subsection{Indigenous Peoples' Conservation Practices}

The respondents highlighted conservation practices for various cultural, traditional or utilitarian reasons. These practices have been put into categories for discussion purposes as shown in Fig. 2. The categories used are: taboos and beliefs, sacred landscapes, spiritual values, royal tradition, livelihood tradition and harvesting methods. There were overlaps in the classifications due to the fact that distinctions between classes are theoretical rather than practical.

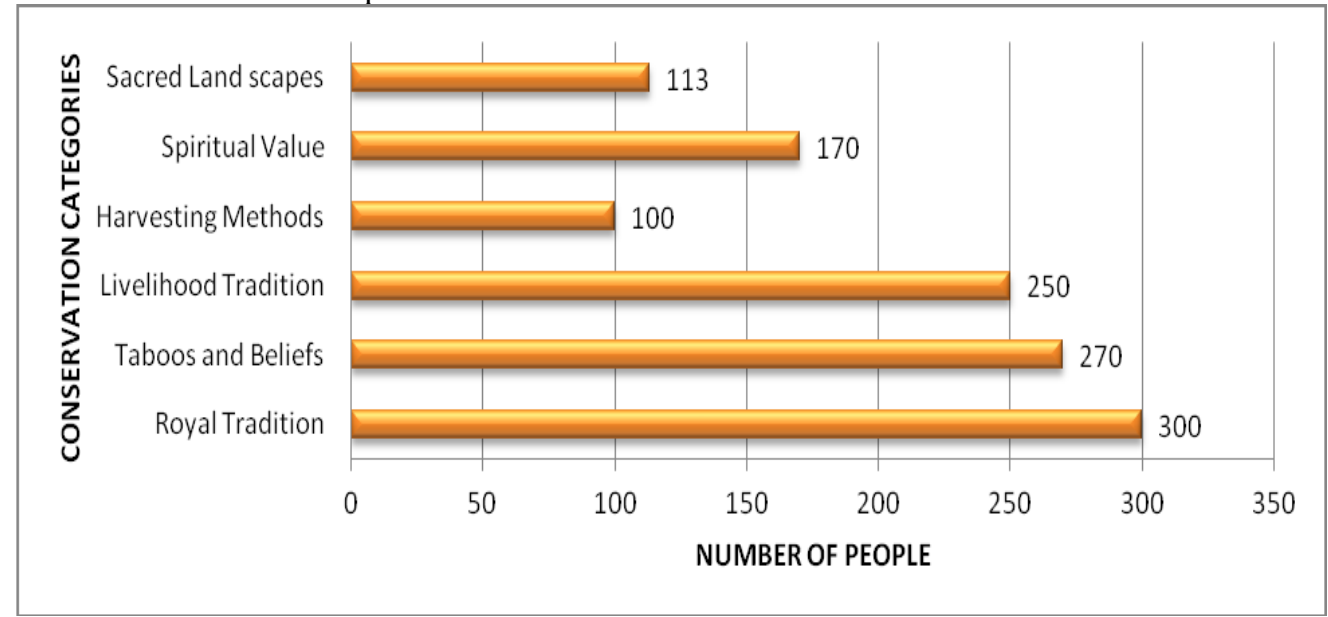

Figure 2: Traditional Conservation Practices

It can be seen from fig. 2 that traditional societies surrounding Kpashimi forest have developed an understanding of their biophysical environment over generations. Their practices and knowledge are grounded in ethical, spiritual and cultural values that they confer to nature. Majority of respondents in the study area showed that Royal traditions, taboos and myths, as well as livelihood tradition play significant role in the conservation of forest biodiversity. This was attested to by over $250(67 \%)$ out of 373 respondents. Other traditional conservation practices highlighted were embedded in the harvesting methods, sacred landscapes protection and perception about nature. This explicates that long before the advent of modern law governing the sustainable use of natural resources, local rules and regulations had enforced conservation agenda.

\subsection{Status of indigenous knowledge application}

The findings in table 3 exhibit that mean values were all above the cut - off point of 2.50 except one item. By and large, the communities confirmed to the declining status of indigenous conservation practices and alluded to the negative consequence of such a trend on biodiversity. It was also clear that the communities would agree to the documentation, revival and enforcement of indigenous knowledge. 
Table 3: Mean score rating of status and constraints to the use of Indigenous Knowledge

\begin{tabular}{|c|c|c|c|}
\hline ITEM STATEMENT & $\overline{\mathbf{x}}$ & SD & DECISION \\
\hline Indigenous conservation practices are declining & 4.84 & 0.194 & Agree \\
\hline $\begin{array}{l}\text { Declining indigenous conservation practices is detrimental to } \\
\text { forest resources }\end{array}$ & 3.51 & 0.062 & Agree \\
\hline Indigenous knowledge need to be documented & 4.27 & 0.090 & Agree \\
\hline Traditional knowledge should be made public & 2.34 & 1.596 & Disagree \\
\hline $\begin{array}{l}\text { Traditional conservation practices should be revived and } \\
\text { enforced. }\end{array}$ & 3.32 & 0.503 & Agree \\
\hline $\begin{array}{l}\text { Indigenous knowledge should be integrated with modern forest } \\
\text { management practices. }\end{array}$ & 4.95 & 0.092 & Agree \\
\hline
\end{tabular}

Note: $\overline{\mathbf{x}}=$ Mean, $\mathbf{S D}=$ Standard deviation

Although respondents agreed to the integration of indigenous knowledge with modern forest management practices, there was a disagreement on making traditional knowledge public as certain knowledge were only kept secret and transferred exclusively by lineage; particularly knowledge of species use for medicinal and spiritual purposes.

\section{Discussion}

The methods in traditional conservation and their likely implication on the overall sustainability goals of forest biodiversity are analysed in the light of modern scientific principles as follows. With regards to traditional rules, traditional conservation practices includes controlled burning of forest landscape and seasonal harvesting of natural resources. The implication for sustainability are to allow regeneration; increase heterogeneity of landscape; improve resilience as a buffer for other disturbances; to avoid over exploitation of natural resources and also to allow regeneration and breeding of species [31,32]. Taboos and belief system involves dos and don'ts without tangible explanations. Such taboos include forbidding killing of young, pregnant or lactating animal; forbidding killing an animal found giving birth etc. This is important where conventional laws cannot be enforced to regulate over exploitation, taboos and beliefs enables people to conserve biodiversity out of respect of traditional norms [33]. Livelihood tradition involves knowledge of nature which induces intrinsic respect for conservation. For instance, restrict hunting of certain species to specific seasons to allow breeding. This promotes conservation of biodiversity [33, 32].

Harvesting methods involves the following conservation practices: Picking of fruits that fell on the ground; no cutting of fruit trees; for firewood, cut only deadwood; debarking of medicinal plants should be done only on one side where sun does not shine directly e.t.c. These were meant to reduce competition among people, birds and fruitivores thereby balancing the ecosystem; reduces deforestation; and regulates the drying rate of trees after debarking and to reduce deforestation [34,35]. Spiritual values are concerned with believes that forests are considered spiritual spaces; ancestral spirits rest in wilderness; a belief that forests needs to be respected. The conservation implication of these includes: reduction of human induced negative disturbances on forest biodiversity; promotes water cycle and sustainability of an ecosystem; reduces human induced negative disturbances on forest biodiversity; and promotes sustainable ecosystem functioning through reduced human impact [33,36]. Sacred landscapes involves believes that forest are considered sacred spaces where human activities is restricted and exclusively reserved; except for certain individuals on certain occasions. This promotes conservation of biodiversity [33].

However, conservation practices among the key participants were reported to be declining for various reasons. For example, elderly people lamented that "three decades back, some tree species could not be used for firewood but nowadays, virtually any tree can be used due to carefree attitude. The other problem threatening use of local knowledge in conservation" they said, "is the modernisation in our society that has affected our youths as they do not regard the local traditional institution". Consequently, the declining knowledge in conservation practices would have negative effect on the conservation perceptions among the younger generations.

The traditional knowledge on biodiversity conservation is examined in the light of contemporary research on traditional knowledge systems and demonstrates their value and usefulness to address the biodiversity conservation at a local scale. The outcome of this study support the findings of Shackleton et al., [37] that certain communities utilize specific forest resources for cultural and traditional purposes rather than utilitarian. This argument is reflected in their results from communities in South Africa where there is the 
demand for medicinal plants that are used for cultural rather than conventional medicinal purposes. Furthermore, a body of conservation and resources management literature suggests that local communities are likely to be better and more efficient managers than centralized agencies [38, 39]. The stated conservation practices in this study further allude to identification of social- ecological linkages and their contribution to the use of locally based ecological knowledge in forest biodiversity conservation. Biodiversity conservation implies the management of human interactions with the variety of life forms and ecosystems so as to maximize the benefits they provide today and maintain their potential to meet future generations' needs and aspirations [40]. Therefore, in the management of biodiversity, both the ecological and the cultural significance of forests need to be recognized [41]. The challenge now is to bring together indigenous knowledge, values and management practices with modern science, in order to create sustainable and culturally appropriate management strategies.

\section{Summary And Conclusion}

The study examined indigenous knowledge and practices performed in some communities surrounding Kpashimi Forest Reserve, with respect to the use and conservation of forest resources. This study has discovered certain fundamental issues: First, local communities depend directly on their natural environment for livelihoods and other religious or spiritual purposes. Second, they also possess valuable ecological knowledge and experiences in local conservation techniques based on decades of traditional practices. Third, it also demonstrated interplay between societal norms, community livelihoods and conservation within the sustainability framework. This body of knowledge from local communities is an essential building block in the conservation strategy of biodiversity especially outside protected areas. Today resources conservation is undergoing a paradigm shift towards a more bottom-up approach which emphasizes the role of local knowledge for decentralized management to local communities. Such devolution becomes a viable conservation approach only if community forestry management strategies are adopted and implemented across forest reserved areas in Nigeria. Through this way local communities will be empowered as resources managers, strengthen governance structures and enhance their sustainable livelihoods.

This study recommends (i) the strengthening of local regulations that encourage sustainable use of forest resources; (ii) encourage community based natural resources management at grass root levels; (iii) study alternatives to the most used species to reduce the selection pressure on a small number of species currently under heavy exploitation; (iv) develop and incorporate in education curriculums indigenous ecological knowledge to foster acceptance and consciousness of conservation of the younger generations. Furthermore, there is the need to further study the relationships between indigenous people's livelihoods, governance and overall resources conservation.

\section{Acknowledgement}

We acknowledge the technical support of the Forestry Unit, Ministry of Environment and Forest Resources, Minna, Niger State. We thank you for providing invaluable assistance during the study. We appreciate the assistance provided by the local forest guards. All community leaders are highly appreciated for patiently responding to our many and sometimes lengthy questions.

References

[1] IUCN (International Union for Conservation of Nature). Redlist of threatened species; [accessed 2012 Jan 06]. Available from: http:// www.iucnredlist.org. (1996).

[2] IUCN, (International Union for Conservation of Nature). IUCN Red List Categories and Criteria: version 3.1. IUCN Species Survival Commission, IUCN, Gland, Switzerland (2001).

[3] IUCN (International Union for Conservation of Nature). Redlist of threatened species (2006); [accessed 2013 March 15]. Available from: http:// www.iucnredlist.org.

[4] IUCN (International Union for Conservation of Nature). Redlist of threatened species(2008); [accessed 2013 April 25]. Available from: http:// www.iucnredlist.org.

[5] J.H. Lawton and R.M. May. Extinction rates. OUP, Oxford. (1995)

[6] Royal Society. Measuring Biodiversity for Conservation. Policy document (2003) 11/03. http://www.royalsoc.ac.uk. Retrieved $6 / 5 / 12$

[7] Millennium Ecosystem Assessment [MA], Millemium Ecosystem Assessment: Ecosystem and Human well-being: Synthesis Report, Island Press, Washington D.C. USA. (2005)

[8] UNEP/CBD (UnitedNations Environmental Programme/Convention on biological Diversity). Sustaining life on Earth: how the convention on biological diversity promotes nature and human well-being (1992). [accessed 2011 Jan 20]. Available from: http:// www.biodiv.org/doc/publications/guide.asp.

[9] Convention of Biological Diversity - CBD, (2002). Global strategy for plant conservation: Refinement of the 16 Targets. $\mathrm{UNEP} / \mathrm{CBD} / \mathrm{COP} / 6 / \mathrm{INF} / 21 / \mathrm{Add} .1$.

[10] T.Noguchi, M.A. Salam., M. Koike, Factors influencing the sustained participation of farmers in participatory forestry: a case study of Central Sal forests in Bangladesh. Journal of Environmental Management, 74: 43-51 (2005).

[11] E. D.G.Fraser, A.J. Dougill, W.E Mabee, M. Reed, McAlphine., Bottom-up and top down: Analysis of participatory processes for sustainability indicators identification as a pathway to community empowerment and sustainable environmental management. Journal of Environmental Management, 78: 114-127 (2006). 
[12] UNCED (United Nations Conference on Environment and Development), Agenda 21, Chapter 26 : Recognising and Strengthening the Role of Indigenous People and their Communities. United Nations Conference on Environment and Development, June 314,1992. Rio de Janerio, Brazil (1992)..

[13] L. Grenier, Working with Indigenous Knowledge : A Guide for Researcher, International development centre : Ottawa (1998).

[14] M. Johnson, (ed.) Lore: capturing Traditional Environmental Knowledge. International Development Research Center, Ottawa Ontario, Canada ,(1992).

[15] F. Berkes, J. Colding, and C. Folke., Rediscovery of traditional ecological knowledge as adaptive management. Ecological Applications 10:1251-1262 (2000)..

[16] J.T. Inglis, Traditional Ecological Knowledge,: concepts and cases. Canadian Museum of Nature.,Ottawa, Ontario, Canada (1993).

[17] M. M. R. Freeman, and L. N. Carbyn, , editors. Traditional Knowledge and renewable resource management in Northern regions. Boreal Institute for Northern Studies Edmonton, Alberta, Canada (1988).

[18] J. Mailhot, Traditional ecological Knowledge; the diversity of Knowledge system and their study. Great Whale Environmental System: Background paper No. 4 Montreal, Canada (1993).

[19] B. Hansen, Editors Report on the seminar on integration of Indigenous People and their Knowledge,Reykjavik, Iceland, September, 1994 Ministry for the environment (1 celnd), Ministry of the environment, (Denmark) (1994).

[20] P. Colorado, Bridging Native and Natural Science. Convergence XX1(2/3) (1988). 49-67

[21] A.O. Kawagley, A yupiaq worldview: a pathway to ecology and spirit. Waveland press, Prospect heights II-Ilinnois, U.S.A. (1995).

[22] V. Deloria, If you think about it you will see that it is true. Revision 18 (3)37-44 (1996)

[23] J. Kremer, Evolving into what, and for whose purpose? Reading Bateson. Re Vision 18(3)27-36 (1996).

[24] A. Agrawal, Dismantling the divide between indeginous and scientific knowledge. Development and change 26(3) 413-439 (1995).

[25] FAO -Food and Agriculture Organization, Forest resources assessment 1990 global synthesis. FAO Forestry Paper 124, Rome, Italy. (1995).

[26] J.A. Sayer, J.K. Vanclay, and N. Byron, Technologies for Sustainable Forest Management: Challenges for the 21st Century. Occasional Paper No 12, CIFOR, Bogor, Indonesia, (1997). 12 p

[27] FORMECU, Forest Management Evaluation and Co-ordinating Unit (1994) World Bank/Government of Nigeria Forestry III project Vol. VI Environmental Assessment, Forest Management Component, kpashimi Forest Reserve, Final Draft (1994).

[28] I.A. Jaiyeoba, and P.E. Essoka, 'Soils and Vegetation' in The Middle Niger River Basin : A field course hand book. Department of Geography, Ahmadu Bello University, Zaria. (2006).

[29] T. Yamane, Statistics: An Introductory Analysis, $2^{\text {nd }}$ Ed., New York: Harper and Row. (1967).

[30] R. Tripp, and J.Woolley, On-farm research: the planning stage. CIMMYT, Mexico and CIAT, Colombia (1989).

[31] A.R.E. Sinclare, and A.E. Bryom, Understanding Ecosystem Dynamics for Conservation of Biota. Journal of Animal Ecology (2006). 75: $64-79$.

[32] T.Berg, Land use, cultural landscape and the conservation of biodiversity. In Olsson, G. et. al (eds). Biodiversity and sustainable Agriculture. Discussion paper No.3 14-17 august 1996. Ekanäs, Sweden. (1996).

[33] D.N. Pandey, Wildlife, National Park and People. Indian Forester 119: 521-529.( 1993).

[34] P.A.D. Nunes, and J.C.JM. van den Bergh, Economic Valuation of Biodiversity: Sense or Nonsense? Ecological Economics (2001). 39:203-222.

[35] A. Lanis, C.kanyan, and P. Bunde, Patterns of Traditional Land Control among three Kenyah groups. In Eghenter,C., Sallato, B. and Devung G.G. (eds). Social Science Research and Conservation Management in the Interior of Borneo, Unveiling Past and Present Interactions of People and Forests. CIFOR, WWF Indonesia, UNESCO and Ford Foundation (2003).

[36] G.P. Nablam, Cultures of Habitat: On Nature, Culture and Story. Counterpoint press, USA. (1997).

[37] M.C. Shackleton, S.E.Shackleton, E.Buiten, N. Bird, The importance of dry woodlands and forest in rural livelihoods and poverty alleviation in South Africa. Forest Policy and Economics (2007) 9: 558-577.

[38] A. Agrawal, and G.N.Yadama, How do local institutions mediate market and population pressures on resources? Forest Panchayats in Kumaon, India. Development and Change, (1997) 28(3), 435-465.

[39] J. C, Ribot, Waiting for democracy. The politics of choice in natural resources decentralization. WRI Report Washington DC. World Resources Institute (2004)

[40] W.V. Reid, and K. R. Miller. Keeping options alive: the scientific basis for Conserving biodiversity. World Resour. Inst., Washington, D.C. (1989). 128pp

[41] D. Donovan, and R. Puri, Learning from traditional knowledge of non timber forest products: Penan Benalui and the autecology of Aquilaria in Indonesian Borneo. Ecology and Society (2004). 9(3): 3 